\title{
Multicriteria analysis applied to the management of urban pluvial waters
}

\section{Análise multicriterial aplicada à gestão das águas pluviais urbanas}

\author{
Danniel Cláudio de Araújo ${ }^{1}$, Pedro Oliveira da Silva ${ }^{2}$, Wilson Fadlo Curi ${ }^{3}$ and Jaime Joaquim da Silva Pereira Cabral ${ }^{2}$ \\ ${ }^{1}$ Instituto Federal de Educação, Ciência e Tecnologia da Paraíba, Patos, PB, Brazil \\ ${ }^{2}$ Universidade Federal de Pernambuco, Recife, PE, Brazil \\ ${ }^{3}$ Universidade Federal de Campina Grande, Campina Grande, PB, Brazil \\ E-mails: dannielclaudio@gmail.com (DCA), eng.pedroos@gmail.com (POS),wfcuri@gmail.com (WFC), jcabral@ufpe.br (JJSPC)
}

Received: January 06, 2016 - Revised: July 07, 2016 - Accepted: November 16, 2016

\begin{abstract}
The urbanization process significantly changes natural drainage processes within a river basin, for instance with the increase of volume of rainwater drained superficially it also increases the peak flows of water bodies, degradation of the water quality, and the sediment generation, among others. Rainwater drainage management plays a key role in urban areas, becoming increasingly complex, involving not only hydrological and hydraulic aspects, but also environmental, social and health issues, as well as other technical and high costs issues. This complexity leads, increasingly, to the use of multicriteria analysis as a support for decision-making. To deal with this, this work aimed to apply a multicriteria analysis methodology, using PROMETHEE method, to issues of urban rainwater drainage. The results indicated that the application of multiparticipative decision making and multicriteria analysis to possible scenarios of hydraulic interventions is well suited to reality.
\end{abstract}

Keywords: Rainwater management; Multicriteria analysis; Decision making.

\section{RESUMO}

O processo de urbanização altera significativamente os processos de escoamento natural da bacia hidrográfica, com o aumento do volume das águas pluviais escoadas superficialmente, incremento das vazões de pico dos corpos d'água, degradação da qualidade da água, geração de sedimentos, entre outros. A gestão das águas pluviais tem, então, um papel fundamental em uma área urbana, este processo vem se tornando cada vez mais complexo, envolvendo não somente aspectos hidrológicos e hidráulicos, como também questões ambientais, sociais e sanitárias, além dos aspectos técnicos e de custos usualmente considerados. Esta complexidade leva, cada vez mais, ao uso da análise multicritério como suporte a decisão. Neste sentido, este trabalho objetiva a aplicação de uma metodologia de análise multicriterial aplicado a drenagem urbana, com o auxílio do PROMETHEE. Os resultados indicaram que a aplicação de análise de multicritério agregado aos cenários de intervenções hidráulicas se adequa bem à realidade, pois permite incluir uma gestão participativa.

Palavras-chave: Gestão de aguas pluviais; Análise multicriterial; Tomada de decisão. 


\section{INTRODUCTION}

Urban streams play important roles for cities rainwater drainage. In addition to being essential for the drainage of rainwater, they recharge the aquifers, maintain water storage along the banks, influence the local temperature and provide an esthetic effect for contemplative leisure. However, most urban waterways are degraded, resulting from an urbanization process without proper planning and without offering adequate sewage and drainage services.

According to Tucci (2002), developed countries have found that the costs of channeling streams are very high and had already abandoned this type of solution in the early 1970s. Developing countries, on the other hand, have systematically adopted this measure and, as a result, have had increased costs and losses. The appropriate urban rainwater drainage management makes possible the urban streams to become part of a healthier environment.

For decades, rivers have been reintroduced as living elements in the urban landscape, recovering the ecological, social and hydrological functions of urban waterways. This approach has been adopted by a number of countries, improving both the health of the streams and the quality of life of the inhabitants of the cities (RIGOTTI; POMPÊO, 2011).

Practices aimed at revitalizing urban streams have proven to be successful in the rescue of their hydraulic, hydrological, ecological and social functions in various cities. This indicates that it is essential to change paradigms regarding the management of urban streams (PREUSS et al., 2013).

Limeira et al. (2010) describe in detail the various names that are attributed to the process of improving river characteristics (revitalization, restoration, requalification, remediation, etc.). In this paper, the controversy regarding the names has been avoid and revitalization of urban streams was used. It includes the process of recovery, conservation and environmental preservation, through the implementation of integrated and permanent actions that promote the sustainable use of natural resources, improvement of socio-environmental conditions, increase in quantity and improvement of water quality for multiple uses.

Regarding this subject, new methodologies are being developed, aimed at assisting the decision making process. The scenarios are drawn based on an analysis of the current situation and the probable future conditions of degradation of the watercourses. It targets to enable public managers and the population in general to reflect on hydro-environmental issues, through continuous and integrated actions, which aim the restoration of rivers and streams in urban areas. The integration of natural, urban, social, and management variables also becomes essential within the decision-making process.

Thus, the formulation of methodologies based on indexes and indicators focused on the characterization of these water systems through selected criteria, utility functions and preferences, based on the Multicriteria Decision Analysis (MCDA), especially the PROMETHEE II Method (Preference Ranking Method for Enrichment Evaluation) become important tools that can contribute to the improvement of the management of this scenario. This present work aimed to carry out a multicriteria analysis study to support the decision making process, as well as to reflect on the possibility of starting a more participatory management process for urban waterways, as provided by Federal Law (BRASIL, 1997).

\section{MULTICRITERIA ANALYSIS}

Traditional problem-solving methods, which seek to frame problems in categories, focus on the choice of alternatives and the search for an optimal solution, based exclusively on the rules of rationality, disregarding the subjectivity of the actors involved in the decision-making process (KEENEY, 1992; ENSSLIN et al., 2001). These methods are not able to deal with complex situations, which require important decisions and are characterized by the following: uncertainties (path, objectives, alternatives, actors, etc.); conflict of values and goals; differences in power relations; multiple assessment criteria (often obscure at first); an infinite amount of information (qualitative and quantitative) which are usually incomplete; and complex situations that require creative and even unprecedented solutions.

According to Ensslin et al. (2001), traditional problem-solving methods are only adequate to solve well-defined problems such as logistics, production control and inventory control. However, according to Schön (1982) apud Ensslin et al. (2001), decision-making processes for complex problems are never the same and therefore complex decisions are unique.

For complex situations, it is indispensable to incorporate the subjective aspects, explaining them and quantifying them. Both the qualitative factors (strongly influenced by the actors' perception) and the quantitative factors (costs, physical characteristics, etc.) inherent in the problem must be taken into account. The alternatives need to be analyzed in terms of their repercussions on the established objectives. The decision taken should consider the perceptions of all decision-makers. According to Ensslin et al. (2001) and Keeney (1992), the MCDA analysis, due to its constructivist paradigm, incorporates all these aspects.

Zuffo et al. (2002) state that, although the literature associates multicriteria analysis with multiobjective methods, these two concepts are quite different. According to the authors, an objective represents an ideal for a decision maker or a group of decision makers and it should represent a general agreement within a decision context, either with respect to time or spatially. On the other hand, criteria represent the translation of the objectives into characteristics, qualities or measures of performance for each one of possible alternatives.

Santos (2004) points out how the decision-makers have difficulty to understand the data and information, as well as their interrelationships in complex situations, and also advocates the adoption of a formal planning strategy, that does not dispense with an analysis methodology aimed at reducing the subjectivity of evaluations and facilitating dialogue among decision-makers.

Multi-criteria methods are intended to support the decision-making process (not necessarily to provide a solution). Curi and Curi (2010) argue that the objectives of multicriteria analysis are basically to structure the problem in the process of choosing between two or more decision alternatives.

In the structuring of the problem, the major challenges are with the representation and formalized organization of the 
problem for learning, investigation / analysis, discussion and search for a solution. In turn, in the choice between two or more alternatives, certain problems arise. for example: use of different criteria (consequences), which may be contradictory; different criteria opinions among the decision makers; incorporation of decision makers judgments of criteria importance's; insatisfaction of some decision maker with the solution; use of qualitative or quantitative data (up to different orders of magnitude) that lead to more than one "optimal solution". Figure 1 shows the phases of the multicriteria analysis.

What all of this shows is that the participatory process in the construction of indicators used to support water resources management needs to involve the use of participative multicriteria techniques as it involves multiple users and multiple variables, making it complex and difficult to solve.

This is because attempting to solve problem (s) from conflicting objectives and with multiple understandings can entail a diverse range of solutions.

\section{Multicriteria methods applied to the management of rainwater in the urban environment}

Decisions aimed at the management of water resources in the urban environment are complex and involve various conflicting social, economic and political objectives (LIU; STEWART, 2004).

Decisions seeking conservation alternatives in the urban area involve not only public power, but also water concessionaires, industries that use water as the main source of their manufacturing process and the general population. Liu and Stewart (2004) point out that, in recent years, support for multicriteria decision-making has been vigorously applied in decisions regarding water resources management. Hallefjord and Jornsten (1986) apud Liu and Stewart (2004) emphasize that the long-term effects of applying multicriteria decision support methods to natural resource management problems

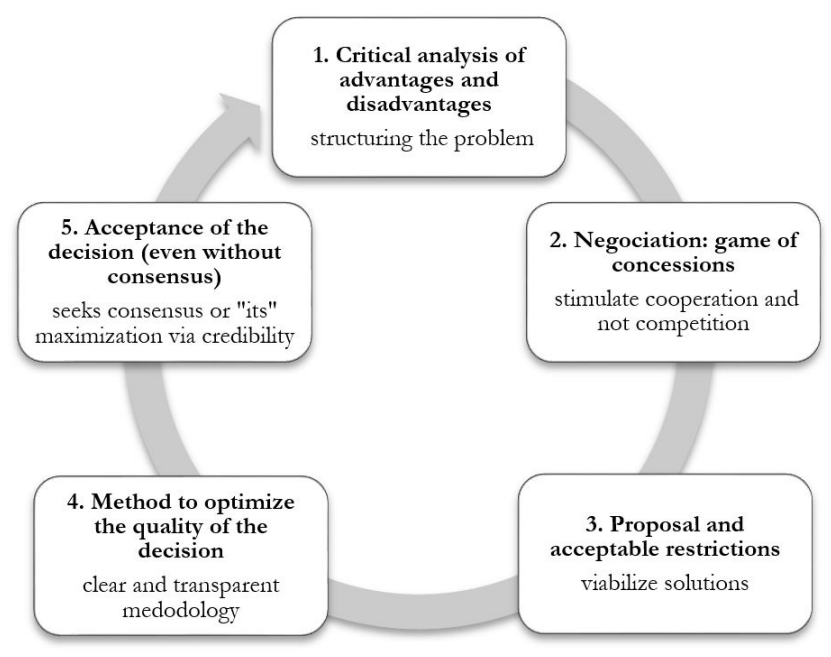

Figure 1. Decision Process of Multicriteria Analysis. Source: Adapted from Curi and Curi (2010). exploit solutions, generate strategic alternatives, and broaden knowledge about the problem, rather than finding ideal solutions.

There are studies in the area of water resources management that use multicriteria decision support methods to help in the prioritization and selection of alternatives directed towards the management of different situations in the areas of sanitation and rainwater.

Simonovic and Verma (2008) argue that decision-making in the area of water resources involving multiple criteria of conflicting aspects is a very complex task, due to the following factors:

- The joint reflection of the economic, environmental, social and technical impacts;

- The difficulty in quantifying the consequences that are important in the selection of an alternative;

- The uncertainties concerning the overall impact of a given alternative.

Hajkowicz and Higgins (2008) cite the most common types of decisions in water resources management that are supported by multi-criteria decision support methods, including:

- Selection among alternatives for water supplies and the infrastructures for water storage;

- Selection of projects for water treatment subject to budget constraints;

- Selection of resource management policies for a given region.

Moura (2004) defined economic and financial indicators for the a priori assessment of urban drainage systems and the integration of the indicators with performance indicators representing technical, environmental and social efficiency aspects. Based on the use of these indicators, a decision-making methodology involving multicriteria analysis was developed, integrating both performance and cost indicators.

Matias et al. (2015) elaborated a decision support model to prioritize compensatory measures, aiming at the control of urban floods. Thus, criteria were defined that made it possible to evaluate potential alternatives with respect to the environmental, social economic and hydrological aspects. The decision support method chosen to support modeling was the PROMETHEE II multicriteria method.

Cardoso and Baptista (2011) proposed a methodology aimed at the diagnosis and evaluation of intervention alternatives to minimize the negative impact of urbanization on the environment and the population. The analysis system in question is based on a qualitative evaluation of the interventions using indicators proposed by the authors and weighted through consultations with specialists. The analysis is structured in three distinct phases: the delimitation and diagnosis of the section of the watercourse that will undergo intervention, the identification of alternatives, and evaluation of the alternatives. This was conducted through a performance analysis of the proposed solutions, based on the aggregation of the indicators, by means of simple weighting. 


\section{PROMETHEE method}

Vincke (1992) suggests that to construct an outranking method, each criterion be evaluated by the weight $p_{j}$. Weights are measures of relative importance of each criterion. If all criteria have the same importance for the decision maker, then all weights can be taken as equal (BRANS et al., 1986). These are expressed through scales, which be cardinal, verbal, or ordinal.

The weights of the criteria allow the preferences of decision makers and their impact on the ordering of alternatives to be expressed explicitly. They can be explained in several ways, but none can guarantee a result more accurate than the others (MOSHKOVICH et al., 1998).

The PROMETHEE methods, since they were first proposed have not ceased to be the object of development and complementary adaptations.

The following implementations of the method are described in the literature (BRANS; VINCKE, 1985; BRANS et al., 1986; BRANS; MARESCHAL, 2002):

PROMETHEE I: establishes a partial pre-order among the alternatives;

PROMETHEE II: ranks the alternatives, establishing a decreasing order of the net flow; Establishes a complete pre-order between the alternatives and is used for the ordering problem;

PROMETHEE III: extension of the notion of indifference, with probabilistic treatment of flows;

PROMETHEE IV: establishes a complete or partial pre-order and is used for the problem of choice and ordering for situations in which the set of viable solutions is continuous;

PROMETHEE V: after establishing a complete order among the alternatives (PROMETHEE II), restrictions are introduced, identified in the problem for the selected alternatives, incorporating an entire optimization philosophy;

PROMETHEE VI - when the decision maker is not able or does not want to define the weights for the criteria precisely, making it possible to specify ranges of possible values instead of a fixed value for each weight, establishing a complete or partial pre-order. It is used for the problem of choice and ordering.
One of the limitations of PROMETHEE is that it does not provide specific guidelines for determining these weights, but assumes that the decision maker is able to weigh the criteria adequately when the number of criteria is not very large (MACHARIS et al., 2004).

As previously mentioned, the PROMÉTHEE II method was used aiming at a complete ordering of the alternatives, avoiding any incomparability, a characteristic best suited the problem under consideration. The use of PROMÉTHEE II requires the knowledge of some concepts used in its construction phase of establishing the classification relationship:

- wj is the weight of criterion $j$, which signifies the importance that the criterion has in relation to the other criteria;

- $g j(a)$ is the value or performance of the alternative to criterion j;

- q represents a value considered as an indifference limit in the comparison of two alternatives with respect to a criterion $\mathrm{i}$;

- $p$ represents the preference threshold, that is, the smallest value for [gj (a) - gj (b)] above which there is a strict preference;

- $F j(a, b)$ is the preference function, a value that varies from 0 to 1 and represents the behavior or attitude of the decision maker against the differences coming from the pairwise comparison between the alternatives, for a given criterion $\mathrm{i}$, indicating the intensity of preference with respect to the difference gj (a) - gj (b) (BRANS; MARESCHAL, 2002). These are the six most commonly used forms, as shown in Chart 1.

From the values of the functions of preference and of the weights assigned to each criterion the degree of outranking of the alternative $a$ over alternative $b$, called the preference index, is calculated as follows:

Chart 1. Forms for preference function.

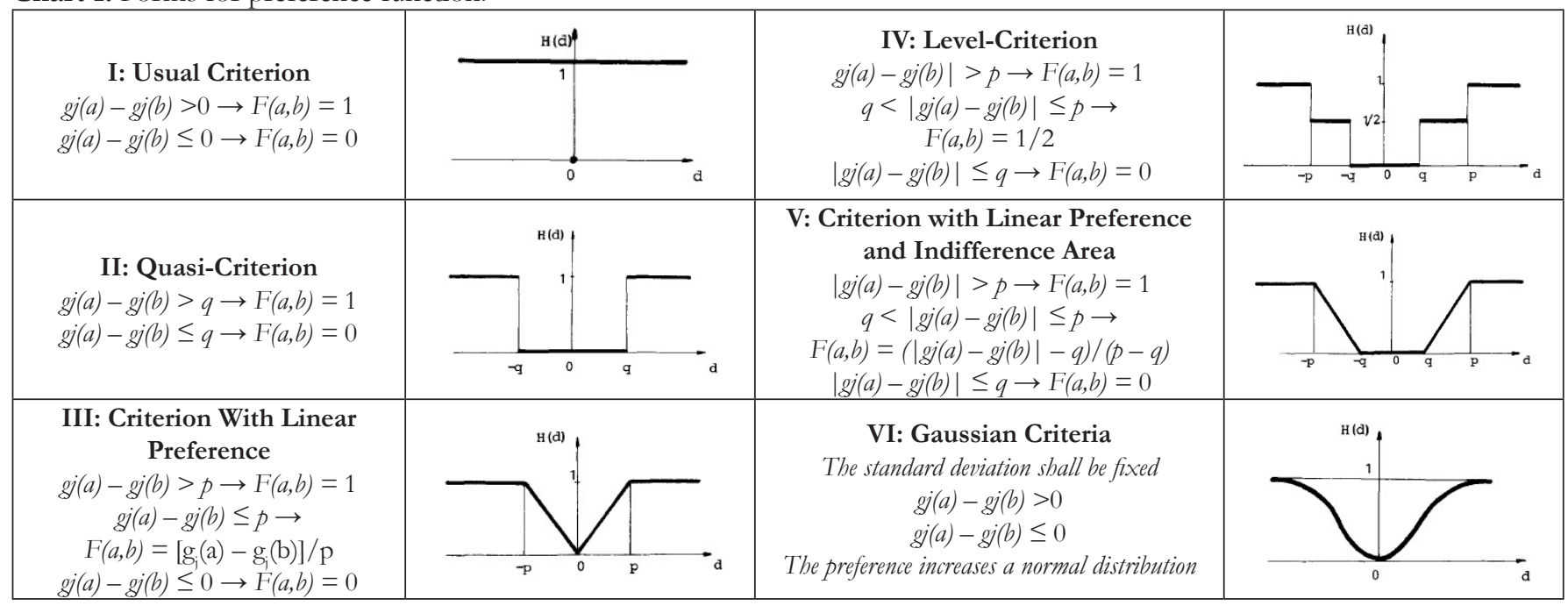

Source: Adapted from Bran and Marechal (1986), Almeida and Costa (2003). 
$\pi(a, b)=\frac{1}{P} \sum_{j=1}^{n} p_{j} F_{j}(a, b)$, onde: $P=\sum_{j=1}^{n} p_{j}$

The preference index defines the valued outranking relationship of one alternative over another and is used to determine the ranking of the alternatives (BELTON; STEWART, 2002).

Brans et al. (1986) indicate that the next step of the method is to calculate the positive and negative outranking values for each identified flow alternative. The positive flow (or outflow), expresses how much alternative $a$ outranks the others $\left[Q^{+}(a)\right]$. The higher $Q^{+}(a)$, is, the better the alternative, and is calculated as follows:

$Q^{+}(a)=\sum_{b \in A} \frac{\pi(a, b)}{n-1}$, né o número de alternativas

The negative flow (or inflow) indicates how much an alternative $a$ is outranked by the others, , $Q(a)]$. The smaller $Q(a)$, the better the alternative, is calculated using the following expression:

$Q^{-}(a)=\sum_{b \in A} \frac{\pi(b, a)}{n-1}$

There is also a valued outranking net flow, which is nothing more than the difference between the outflow and the inflow, representing the balance between the strength and the weakness of the alternative. The higher the net flow, the better the alternative. This is calculated as follows:

$Q(a)=Q^{+}(a)-Q^{-}(a)$

Thus, with the PROMETHEE II method, it is possible to rank the alternatives by obtaining a value for each one, which will be its net flow. This will then be used in the second step of the PROMETHEE V method; ie, the coefficients of the objective function of the entire linear programming will be the values of the net flow obtained in the first phase of the method, that is, resulting from the PROMETHEE II (ABU-TALEB; MARESCHAL, 1995). Thus, the entire linear programming model is described by Equations 5 and 7 .

$\operatorname{Max} \sum_{i=1}^{k} \phi\left(a_{i}\right) x_{i}$

Where:

$x_{i} \in\{1,0\} i=1,2,3, \ldots, n$

$n$ is the number of alternatives $s \cdot a$ :

$$
\sum_{i=1}^{n} a_{i} x_{i} \leq C
$$

Where:

$a_{i}$ represents the values of the evaluations made for each alternative over criterion $i$;

$x_{\mathrm{i}}$ is the decision variable;

$\mathrm{C}$ is the value of the constraint.

The coefficients of the objective function (5) are the values associated to the net flow obtained from the application of PROMETHEE II. In this way, through a whole linear programming, a subset of alternatives is obtained that satisfies the constraints imposed in the problem. A new net flow is also obtained. If $x$ is equal to one (1), the alternative was selected and these are the best actions with respect to constraints, otherwise $x$ has a value equal to zero (0). The purpose is to obtain as many flows of valued outranking as possible, taking into account constraints that may include factors such as budgeting, personnel, investment, and marketing (BRANS; MARESCHAL, 1998).

\section{METHODOLOGY}

The choice of a formal method to aid in decision making is a complex step. Almeida (2010) emphasizes that multicriteria methods have different axiomatic structures or hypotheses and can not be applied in just any way to the same problem without taking into account the differences. Therefore, it is important that the decision maker has sufficient knowledge of the problem to be analyzed, as to the context of available information, its degree of precision and the type of problem that will be addressed. In this work, we adopted PROMETHEE as the multicriteria method.

The model proposed was to analyze the priority of decision makers in relation to urban flood control measures through the overclassification method described in the previous item. Figure 2 illustrates the methodology applied in our case study.

After defining the method to be used and all evaluation parameters, a matrix with the alternatives under consideration and all related criteria (alternatives $\mathrm{x}$ criteria) that had been established is constructed.

It is possible that in this matrix some criteria could have been evaluated directly without any interference on the part of the decision maker, and could be measured based on previous studies, as is the case of the cost criterion where the monetary value employed is.

However, there could be criteria that required a more subjective judgment, not being able to be evaluated directly with

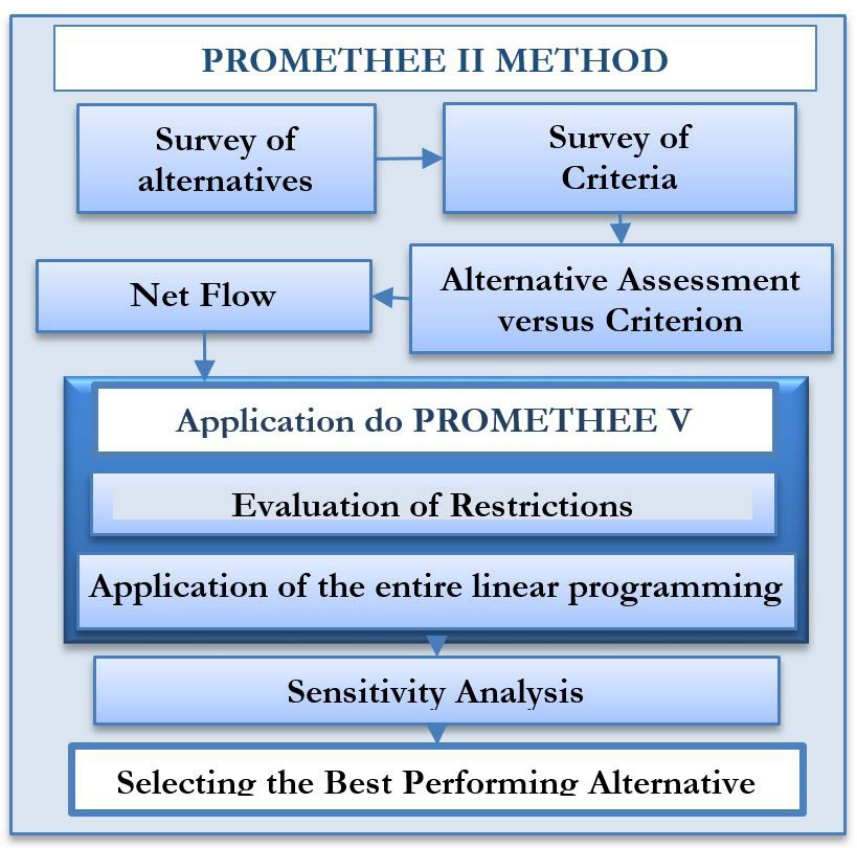

Figure 2. Flowchart of the analysis methodology. 
specific values. In these cases verbal scale are used, to simplify and assist the decision maker during the evaluation.

Given this, the result of a multicriteria model of decision support should not be seen as an exact answer to the solution of the problem, but rather as a recommendation. Thus, this model does not translate into the obligation to implement the winning alternative (although it has better performed to the other ones), but serves as recommendation, leaving the decision maker free to implement any of the other chosen alternatives.

\section{CASE STUDY}

The present study sought to evaluate the performance of alternatives related to a sub-basin of the Sanbra channel (waterways receiving masonry or concrete sidewalls are called channels), tributary of the Jiquiá river, which is part of the network of streams of the Tejipió river basin (Figure 3), located in the western part of the city of Recife. In this region there are points of flooding when intense rains occur.

It is important to point out the role of civil society in the decision-making process, as the local population is the most affected by the drainage problem in the region, making it difficult for people to get about on rainy days. In addition, civil society pays for part of the financing of drainage works through the payment of taxes.

\section{Diagnosis of the study area}

The basin has an area of 39.65 ha with a perimeter of $3748.91 \mathrm{~m}$ and an average waterproofing rate of $88.7 \%$, which classifies it as a densely occupied area. The area is characterized as residential, a sector with disordered occupation (approximately $5.7 \mathrm{ha}$ ) characterized by the municipal government as a ZEIS, a zone of social interest.

With regard to rainwater drainage system, the basin has micro drainage systems built into most of its sites that constitute the downstream main channel. The macro drainage network (Sanbra channel) has an extension of $1.08 \mathrm{~km}$ with a downslope of $0.08 \%$ until its discharge into the Jiquiá river. The channel has different types of coverings, alternating between $279 \mathrm{~m}$ of upstream masonry (Figure 4); 455m of intermediate uncoated river bed, and having, in the final course, variations between masonry and double concrete galleries (Figure 5).

Field visits and division of the sub-basin into sections were carried out based on the following factors: control and monitoring points; soil occupation of each area and existing microdrainage and macrodrainage systems.

\section{Survey of possible intervention scenarios}

From the performed diagnosis, it was possible to survey possible intervention alternatives that could be implemented in the region. The measures proposed by Silva and Cabral (2014) as potential alternatives for the solution to flooding in the study area were adopted.
The set of structural compensatory techniques were divided into 2 groups: the first referring to techniques based on infiltration, therefore, used in regions where the soil had sufficient capacity for infiltration; and the second referring to techniques based on

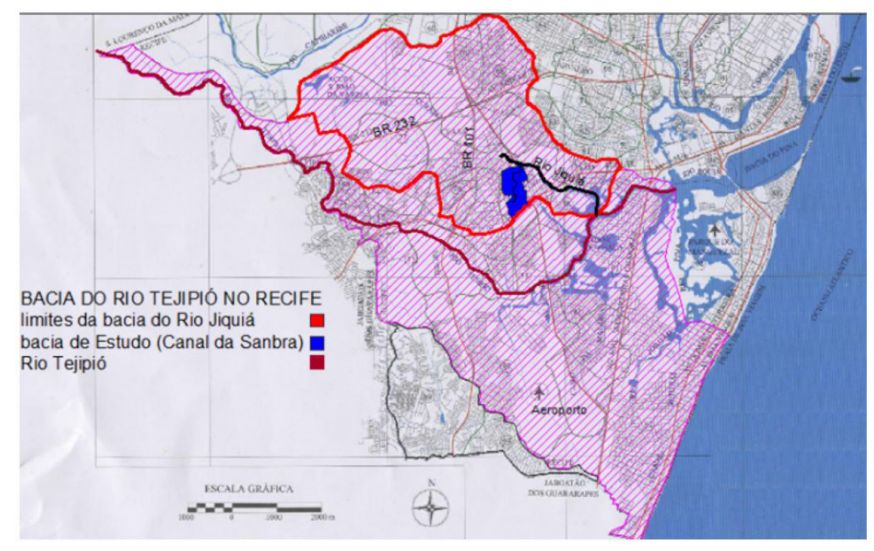

Figure 3. Location of the subbasin in the Tejipió river basin.

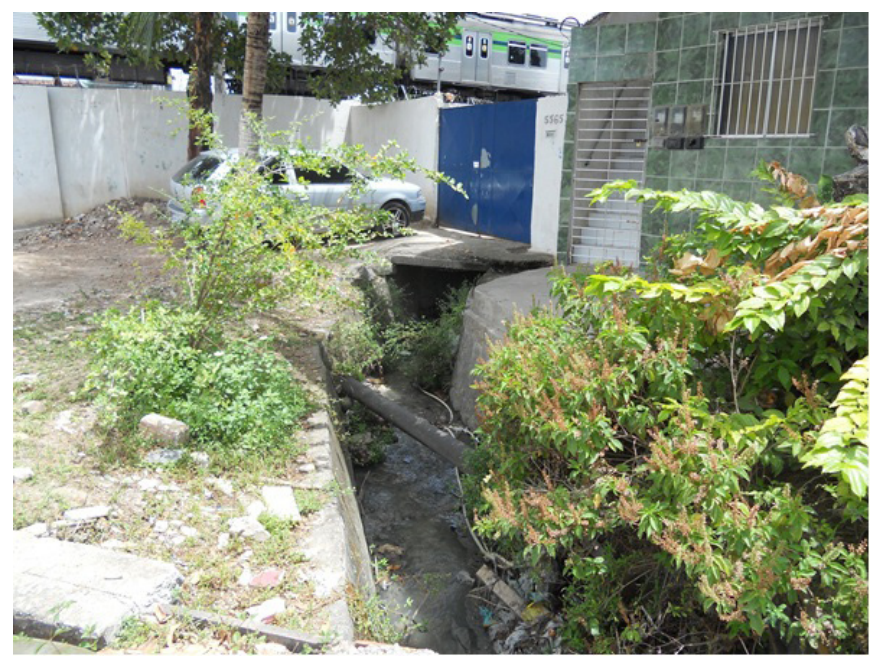

Figure 4. Extent upstream of the Sambra canal.

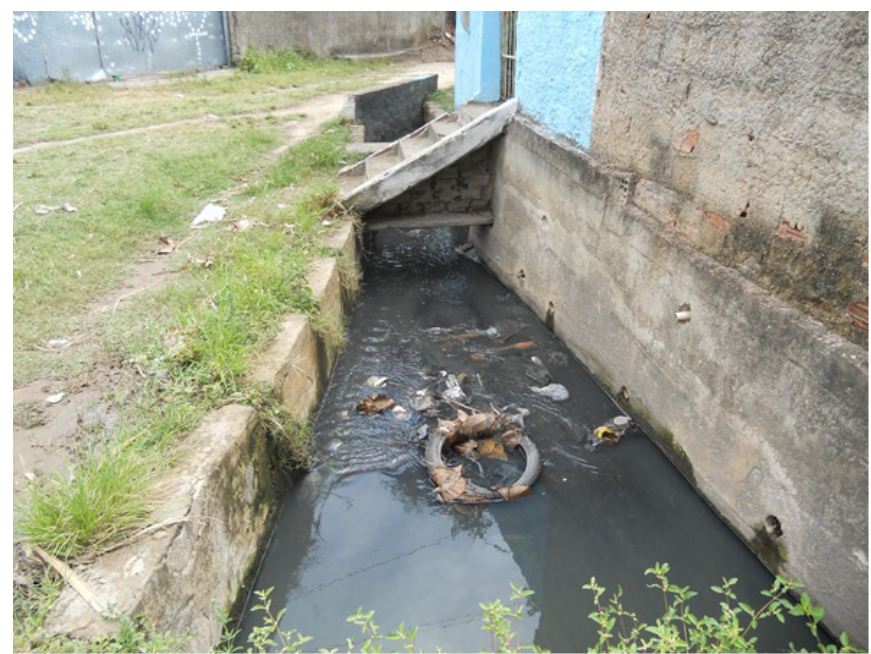

Figure 5. Section downstream of the Sambra channel. 
retention that could be used both in regions with good infiltration capacity and in regions that had little or no infiltration capacity.

This study aimed to evaluate the alternatives based on retention and an alternative solution. The scenarios used for the study were: Detention in batches (A1); Detention in public places (A2); to build a basin detention reservoir (A3) and Graide elevation (A4).

\section{Identification of the analysis criteria}

Environmental, social, economic and hydrological criteria for making the decision were proposed. Because some of the criteria were difficult to quantify, a verbal scale was used according to the following decision, where the sum of the weights of all the criteria is equal to 1 .

\section{I - Environmental}

Impact on water quality (C1): Rainwater pours a large number of different types of pollutants into rivers and streams, contaminating them, and, depending on the type of pollutant, can contaminate groundwater. Thus, the criterion 'impact on water quality' is selected to evaluate the levels (low, moderate and high) of potential contamination risks that can be carried by rainwater. (Table 1).

Sustainability (C2): This criterion was analyzed as to reuse of rainwater. When an alternative includes reuse of rainwater, it will receive the highest evaluation (Table 2).

\section{II - Social}

Risk to public bealth (C3): water is a means of transmitting diseases, so it is important to consider alternatives that reduce the risk of disease to the population as much as possible. Thus, the higher the risk, the lower the evaluation and, consequently, the lower the risk, the higher the evaluation (Table 3).

Social Acceptance (C4): It is known that any interference in the urban environment affects society directly and, therefore, it must take into consideration and agree with the measures proposed by the government, so the criterion "social acceptance" will evaluate public preference for the alternatives proposed for flood reduction. The greater the acceptance, the higher the evaluation attributed to this criterion (Table 4).

\section{III - Economic}

Within the economic criteria three subcriteria were established: implementation, maintenance and operation costs.

Cost of implantation (C5): The values for this criterion were based on studies carried out by Moura (2004), apud Baptista, Nascimento and Barraud (2005), always preferring the alternative with the lower cost.

To enable the calculation of the dimensions of the detention reservoirs in plots, a scenario was considered using for hourly events of $50.6 \mathrm{~mm}$ using the Natural Reservation Loss method (CANHOLI, 2005) and the Rainfall method (BAPTISTA; NASCIMENTO; BARRAUD, 2005). Considering that the area of an average plot in the basin $\left(530 \mathrm{~m}^{2}\right)$, a volume of $7.95 \mathrm{~m}^{3}$ was obtained.

Given the construction of 277 units representing micro reservoirs with $8 \mathrm{~m}^{3}$, with a unit value of $\mathrm{R} \$ 7,000.00$, we obtained a total value for alternative 1 of $\mathrm{R} \$ 1,939,000.00$.

Table 1. Levels of preference for the criterion impact on water quality.

\begin{tabular}{clc}
\hline Verbal scale & \multicolumn{1}{c}{ Description } & $\begin{array}{c}\text { Numerical } \\
\text { scale }\end{array}$ \\
\hline Low & $\begin{array}{l}\text { The alternative will not be } \\
\text { contaminated by diffuse pollution. }\end{array}$ & 0 \\
\hline Moderate & $\begin{array}{l}\text { The alternative will not be } \\
\text { contaminated by diffuse pollution if } \\
\text { there are few interactions. }\end{array}$ & 0.5 \\
\hline High & $\begin{array}{l}\text { The alternative may be contaminated } \\
\text { by diffuse pollution. }\end{array}$ & 1 \\
\hline
\end{tabular}

Table 2. Preference levels for the sustainability criterion.

\begin{tabular}{clc}
\hline Verbal scale & \multicolumn{1}{c}{ Description } & $\begin{array}{c}\text { Numerical } \\
\text { scale }\end{array}$ \\
\hline Low & $\begin{array}{l}\text { The alternative does not enhance the } \\
\text { reuse of rainwater. }\end{array}$ & 0 \\
\hline Moderate & $\begin{array}{l}\text { The alternative includes the reuse of } \\
\text { rainwater for some activities. }\end{array}$ & 0.5 \\
\hline High & $\begin{array}{l}\text { The alternative maximizes the reuse } \\
\text { of rainwater for activities. }\end{array}$ & 1 \\
\hline
\end{tabular}

Table 3. Preference levels for the public health risk criterion for contamination.

\begin{tabular}{clc}
\hline Verbal scale & \multicolumn{1}{c}{ Description } & $\begin{array}{c}\text { Numerical } \\
\text { scale }\end{array}$ \\
\hline Low & $\begin{array}{l}\text { The alternative poses no risk to the } \\
\text { health of society. }\end{array}$ & 0 \\
\hline Moderate & $\begin{array}{l}\text { The alternative may present a risk to } \\
\text { the health of society. }\end{array}$ & 0.5 \\
\hline High & $\begin{array}{l}\text { The alternative presents a high risk } \\
\text { to the health of society. }\end{array}$ & 1 \\
\hline
\end{tabular}

Table 4. Levels of preference for criteria acceptance of society.

\begin{tabular}{clc}
\hline Verbal scale & \multicolumn{1}{c}{ Description } & $\begin{array}{c}\text { Numerical } \\
\text { scale }\end{array}$ \\
\hline Very high & $\begin{array}{l}\text { The alternative will have a positive } \\
\text { impact on the population. }\end{array}$ & 1 \\
\hline High & $\begin{array}{l}\text { The alternative will cause few } \\
\text { positive impacts on the population. }\end{array}$ & 0.75 \\
\hline Moderate & $\begin{array}{l}\text { The alternative will have both a } \\
\text { positive and negative impact on the } \\
\text { population of the region involved. }\end{array}$ & 0.5 \\
\hline Low & $\begin{array}{l}\text { The alternative will have no impact } \\
\text { on society at all. }\end{array}$ & 0.25 \\
\hline Very low & $\begin{array}{l}\text { The alternative will cause negative } \\
\text { impacts on the population. }\end{array}$ & 0 \\
\hline
\end{tabular}


IV - Hydraulic

Peak flow (C6): the criterion "peak flow" aims at evaluating how the alternative implemented can reduce the flow. To do this, the alternatives were simulated in the Storm Water Management Model (SWMM), where the values were compared without the control measure and with each alternative suggested, according to Silva and Cabral (2014).

The values obtained for the reduction of the peak flow for each alternative were: detention in lots $(39 \%)$; detention in public place (42\%); single reservoir in basin (57\%) and Graide elevation $(0)$.

\section{Definition of criteria weights and other parameters}

The values for the criteria weights are summarized in Table 5, obtained according to the preference of specialists in the field. These were normalized, that is, their sum is equal to one.

In addition to the weights for each criterion, a preference function was established, as presented in Table 1, which represents how criteria are compared according to the decision maker's judgment. Thus, for the environmental, social and hydraulic criteria, a type I function was chosen (strict preference), where regardless of the value of the difference in the evaluation of a criterion among different alternatives, the best would be the winner. For the economic criterion, function III (linear criterion) was chosen, where the preference of the decision maker is increased up to a predetermined preference limit (p). The parameter indicating the adopted preference limit was 500,000.00 for criterion C5.

\section{Method of evaluation}

The decision problem is summarized by the evaluation matrix (alternatives versus criteria) presented in Table 6 .

Table 5. Weights of the criteria.

\begin{tabular}{lcc}
\hline & CRITERION & Weight \\
\hline C1 & Water quality & 0.10 \\
C2 & Water reuse & 0.10 \\
C3 & Health risks to the population & 0.10 \\
C4 & Public acceptance & 0.10 \\
C5 & Deployment Cost & 0.30 \\
C6 & Peak Flow Reduction & 0.30 \\
\hline
\end{tabular}

\section{Net flow of Promethee II}

From the results of the pairwise comparisons it is possible to calculate the positive, negative and net flows for each alternative (Table 7), using Equations 2-4, as presented in item 2.2.

In order to construct the valued outranking relation one must compare each couple of alternatives, one by one, observing the positive and negative flows, and obeying the recommendations of the PROMETHEE I method as presented in item 2.2. Thus, the model provided the following ranking of the alternatives: A3, A2, A1, A4 (Figure 6).

Alternative A3 (reservoirs in basin) stood out in relation to the others and was therefore, considered the best alternative according to the preference of the decision maker. Alternative A1 (batch reservoir) would have been the one with the best environmental efficiency, because the water reserved in the lot could be used in the same residence for uses that did not need a more rigorous treatment. However, the high cost made it impracticable, thus requiring a partnership with the city and the users to make it more attractive from the economic point of view.

\section{Lifting constraints and applying whole linear programming}

PROMETHEE $\mathrm{V}$ works from the perspective of the selection of alternatives through existing constraints on the problem. A survey of these constraints can lead to a number of important aspects for the decision maker. Within the area of water resources there are some parameters that can be taken into account as linear constraints on the decision problem. These parameters can represent budgetary limitations, geographic dispersion, environmental impacts, among others (ABU-TALEB; MARESCHAL, 1995).

For the problem in question, budgetary limitations for the implementation of the alternatives by the public sector were adopted as constraints of the problem. It was stipulated that the state government would limit a budget of, approximately, $\mathrm{R} \$ 1,500,000.00$ for implantation of the intervention alternatives. Within this limitation a subset of feasible alternatives that would have to be implanted within these limits should be found. The peak flow also would have to be reduced by at least $30 \%$, which will be a constraint to the implemented alternative.

According to the PROMETHHE $\mathrm{V}$ procedure, the coefficients of the objective function correspond to the net flows obtained in PROMETHEE II. Therefore:

Table 6. Alternative valuation matrix.

\begin{tabular}{|c|c|c|c|c|c|c|}
\hline \multirow{2}{*}{ Alternatives } & \multicolumn{6}{|c|}{ Criteria } \\
\hline & C1 & $\mathrm{C} 2$ & $\mathrm{C} 3$ & $\mathrm{C} 4$ & $\mathrm{C5}$ & C6 \\
\hline Objective & Minimize & Maximize & Minimize & Maximize & Minimize & Maximize \\
\hline A1 & Low & High & Low & Very high & $\mathrm{R} \$ 1.939 .000,00$ & 0.39 \\
\hline $\mathrm{A} 2$ & Moderate & Moderate & Moderate & High & $\mathrm{R} \$ 1.041 .728,00$ & 0.42 \\
\hline A3 & High & Low & High & Moderate & $\mathrm{R} \$ 289.950,31$ & 0.57 \\
\hline A4 & High & Low & High & Low & $\mathrm{R} \$ 288.699,00$ & 0 \\
\hline
\end{tabular}




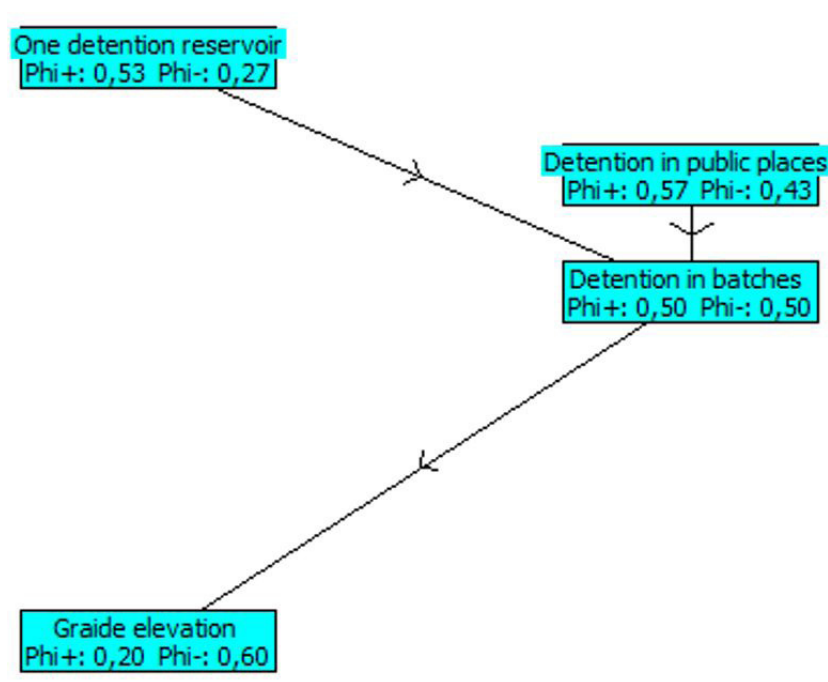

Figure 6. Overclassing flow of alternatives.

Table 7. Net, positive and negative flows of alternatives.

\begin{tabular}{ccccc}
\hline Ranking & Alternative & $Q$ & $Q^{+}$ & $Q^{-}$ \\
\hline $1^{\circ}$ & One basin detention reservoir & 0.27 & 0.53 & 0.27 \\
$2^{\circ}$ & Detention in public places & 0.13 & 0.57 & 0.43 \\
$3^{\circ}$ & Detention in batches & 0.00 & 0.50 & 0.50 \\
$4^{\circ}$ & Greide elevation & -0.40 & 0.20 & 0.60 \\
\hline
\end{tabular}

$\operatorname{Max} Z=0.27 x_{A 1}+0.13 x_{A 2}+0.00 x_{A 3}-0.40 x_{A 4}$

Subject to:

$1,939,000.0 x_{A 1}+1,041,728.0 x_{A 2}+289,950.3 x_{A 3}+288,699.0 x_{A 4} \leq$
$1,500,000.0$

$0.39 x_{A 1}+0.42 x_{A 2}+0.57 x_{A 3}+0.0 x_{A 4} \geq 0,3$

$x_{A 1} \cdot x_{A 2} \cdot x_{A 3} \cdot x_{A 4}=[0,1]$

Where: (8) is the objective function; (9) Implementation budget constraint; (10) Restriction on Reduction in peak flow; (11) restriction on the value of xs. The decision variable xAi corresponds to the variable that represents the alternative of the problem, for example xA1 corresponds to alternative A1.

However, Fontana and Morais (2013) observed that because the objective is to maximize the function, the integer linear programming leaves no possibility of the alternatives with a negative liquid flow enter the subset of the solutions. In this sense, the A4 alternative will not be part of the final solution.

The solution of the problem is given as follows; If the decision variable $\mathrm{xAi}$ has a value of 1 , it means that this alternative is part of the subset of feasible solutions. If xAi has a value of 0 , this implies that the alternative is not part of the subset of feasible solutions.

It can be observed that in the application of the PROMETHEE $\mathrm{V}$ method, by adding the two constraints of budgetary limitation

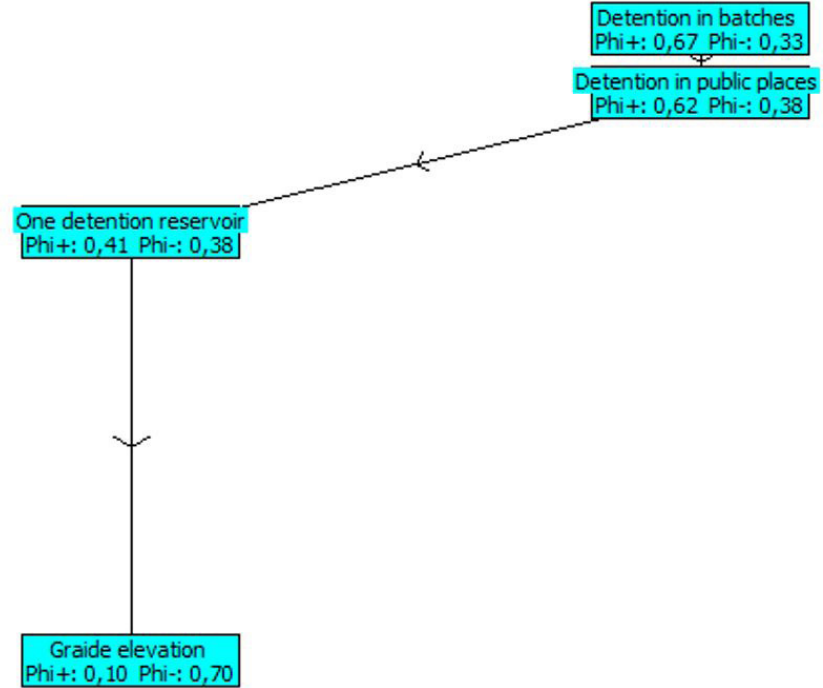

Figure 7. Overclassification flow of the alternatives with a variation of $-15 \%$ of the economic criterion.

and reduction in peak flow, the number of potential alternatives to be applied, aiming at the optimization of rainwater management, decreases considerably. After the simulation, the only selected alternative was the Single Reservoir in the Basin (A3), with a maximum value of the objective function: $\mathrm{Z}$ Max $=0.414$.

This alternative is one of the most recommended within the constraints imposed for improving rainwater management because it considerably reduces the peak flow reduction and the value is within the expected constraint imposed by the decision maker.

\section{Sensitivity analysis}

To verify the consistency of the model and to determine the effect of a variation of a certain parameter on the result, a sensitivity analysis was performed. In this simulation the most important criterion was the economic criterion, so its weight was chosen to undergo variations of $-15 \%$ enabling an evaluation of the behavior of the final result.

Then, as the value of the economic criterion weight decreased by $15 \%$, a value of $5 \%$ was added to the criteria: water quality, water reuse and health risk to the population. Note that with this variation there was a change in the order of the alternatives, observing the following ranking: A1, A2, A3, A4 (Figure 7).

Note that there was a reversal of the position of the first and third alternatives. This inversion can be attributed to the fact that the evaluation for the economic criterion of the two alternatives was compensated in relation to the other criteria where the alternative A1 presented more satisfactory results. For this reason, when we varied the weight of this criterion its ordering changed, showing that the model is sensitive in relation to its evaluations. The other alternatives remained in the same evaluation order.

\section{CONCLUSIONS}

The application of the multi-criteria PROMETHEE method proved to be very effective in helping decision-making in rainwater management when well used, especially when the 
decision maker makes correct choices in relation to the objectives and preferences. The present case study proposes to insert a more participatory approach to the problem of urban drainage. So an ideal alternative would be the one that performs well under all points of view, but it is known that reconciling good performance with all criteria is not an easy task, since in most cases where a successful performance is achieved for one aspect, another aspect may fails to achieve its objective.

However, the idea of compensating general criteria performances, in the case of urban drainage problems, is not a good policy to adopt, since it can generate unsustainable situations. For example, one alternative may be very good from a hydrological point of view, but present a very high cost or a great risk to the health of the population. Therefore, the context itself directs the problem to a valued outranking approach, based on alternative pairwise comparisons, not allowing for compensations among the criteria. Thus, the sought alternatives should provide the best balance among the considered most important criteria according to the preferences of the decision makers.

It was observed through the multi-criteria analysis that one of the most important tools in the choice of the decision process was the correct weighting for the model weights. One of the ways to minimize the arbitrariness of these values would be to expand the number of decision makers and achieving the final weighting using the Analytic Hierarchy Process (AHP) method. The inclusion of the general public in this decision process makes it extremely important to know the public opinion of the population in giving priority to the most important criteria in the scenarios evaluated. One way to improve participatory management in stormwater management is by creating urban river basin committees, already envisaged in legislation, although the committees already exist in the larger basins where conflicts over use is the focus of the discussions.

In this application, in particular, there was no relation of indifference or incomparability between the alternatives. It is worth emphasizing, however, that, depending on the values adopted by the decision maker for the evaluation parameters, these types of relations between the alternatives may arise.

\section{REFERENCES}

ABU-TALEB, M. F; MARESCHAL, B. Water resources planning in the Middle East: application of the PROMETHEE V multicriteria method. European Journal of Operational Research, v. 81, n. 3, p. 500511, 1995. http://dx.doi.org/10.1016/0377-2217(94)00007-Y.

ALMEIDA, A. T. O conhecimento e o uso de métodos multicritério de apoio a decisão. 2. ed. Recife: Editora Universitária, 2010.

ALMEIDA, A. T.; COSTA, A. P. C. S. Aplicações com métodos multicritério de apoio a decisão. Recife: Editora Universitária, 2003.

BAPTISTA, M. B.; NASCIMENTO, N. O.; BARRAUD, S. Técnicas compensatórias em Drenagem Urbana. Porto Alegre: ABRH, 2005.

BELTON, V.; STEWART, T. J. Multiple criteria decision analysis. Kluwer: Academic Publishers, 2002.
BRANS, J. P.; MARESCHAL, B. Multicriteria decsion aid: the Promethee-Gaia solution. Ixelles: Vrije Universiteit Brussel, 1998. STOOTW/288.

BRANS, J.P.; MARESCHAL, B. PROMETHEE-GAIA: une méthodologie d'aide à la décision en présence de critères multiples. Bruxelles: Éditions de L’Université de Bruxelles, 2002.

BRANS, J. P.; VINCKE, P. H. A preference ranking organization method, the PROMETHEE method for MCDM. Management Science, v. 31, n. 6, p. 647-656, 1985. http://dx.doi.org/10.1287/ mnsc.31.6.647.

BRANS, J. P.; VINCKE, P.; MARESCHAL, B. How to select and how to rank projects: the PROMETHEE method. European Journal of Operational Research, v. 24, n. 2, p. 228-238, 1986. http:/ / dx.doi.org/10.1016/0377-2217(86)90044-5.

BRASIL. Lei no 9.433, de 8 de janeiro de 1997. Institui a Política Nacional de Recursos Hídricos e cria o Sistema Nacional de Gerenciamento de Recursos Hídricos. Diário Oficial [da] República Federativa do Brasil, Brasília, DF, 1 jan. 1997.

CANHOLI, A. P. Drenagem urbana e controle de enchentes. São Paulo: Oficina de Textos, 2005. $302 \mathrm{p}$.

CARDOSO, A. S.; BAPTISTA, M. B. Metodologia para avaliação de alternativas de intervenção em cursos de água em áreas urbanas. RBRH: Revista Brasileira de Recursos Hídricos, v. 16, n. 1, p. 129139, 2011. http://dx.doi.org/10.21168/rbrh.v16n1.p129-139.

CURI, W. F.; CURI, R. C. Análise multicriterial material da disciplina de Otimização em Recursos Naturais. 2010. Tese (Doutorado) - Programa de Pós-graduação em Recursos Naturais, Universidade Federal de Campina Grande, Campina Grande, 2010.

ENSSLIN, L.; MONTIBELLER, N. G.; NORONHA, S. M. Apoio à decisão: metodologias para estruturação de problemas e avaliação multicritério de alternativas. Florianópolis: Insular, 2001.

FONTANA, M. E.; MORAIS, D. C. Using PROMETHEE V to select alternatives so as to rehabilitate water supply network with detected leaks. Water Resources Management, v. 27, n. 11, p. 4021-4037, 2013. http://dx.doi.org/10.1007/s11269-013-0393-1.

HAJKOWICZ, S.; HIGGINS, A. A comparison of multiple criteria analysis techniques for water resource management. European Journal of Operational Research, v. 184, n. 1, p. 255-265, 2008. http:// dx.doi.org/10.1016/j.ejor.2006.10.045.

KEENEY, R. L. Value-focused thinking: a path to creative decisionmaking. London: Harvard University Press, 1992.

LIMEIRA, M. C. M.; SILVA, T. C.; CÂNDIDO, G. A. Gestão adaptativa e sustentável para a restauração de rios: Parte I enfoques teóricos sobre capacitação social. RBRH: Revista Brasileira de Recursos Hídricos, v. 15, n. 1, p. 17-26, 2010. http://dx.doi. org/10.21168/rbrh.v15n1.p17-26. 
LIU, D.; STEWART, T. J. Object-oriented decision support system modeling for multicriteria decision making in natural resource management. Computers \& Operations Research, v. 31, n. 7, p. 985999, 2004. http://dx.doi.org/10.1016/S0305-0548(03)00047-9.

MACHARIS, C.; SPRINGAEL, J.; BRUCKER, K. D.; VERBEKE, A. PROMETHEE and AHP: the desing of operation synergies in multicriteria analysis. Strengthening PROMETHEE with ideas of AHP. European Journal of Operational Research, v. 153, n. 2, p. 307317, 2004. http:/ /dx.doi.org/10.1016/S0377-2217(03)00153-X.

MATIAS, G. A.; ALENCAR, L. H.; MORAIS, D. C. Modelo de apoio a decisão para priorização de medidas de controle de inundações urbanas. In: ENCONTRO NACIONAL DE ENGENHARIA DE PRODUÇÃO ENEGEP, 35., 2015, Fortaleza. Anais... Fortaleza: ABEPRO, 2015. p. 1-16.

MOSHKOVICH, H. M.; SCHELLENBERGER, R. E.; OLSON, D. L. Data influences the result more than preferences: some lessons from implementation of multiattribute techniques in a real decision task. Decision Support Systems, v. 22, n. 1, p. 73-84, 1998. http://dx.doi.org/10.1016/S0167-9236(97)00024-9.

MOURA, P. M. Avaliação global de sistemas de drenagem urbana. 2004. 164 f. Dissertação (Mestrado em Saneamento, Meio Ambiente e Recursos Hídricos) - Escola de Engenharia, Universidade Federal de Minas Gerais, Belo Horizonte, 2004.

PREUSS, L. C. S.; LIMA, V. T.; FRANÇA, M. A. L.; LINS, M. P. T.; SELVA, S. F. V.; CABRAL, J. S. P. J. Visão Multidisciplinar para o manejo sustentável das águas pluviais urbanas. O caso do riacho Parnamirim no município do Recife - PE/Brasil. In: WORKSHOP DE MUDANÇAS CLIMÁTICAS E RECURSOS HÍDRICOS DO ESTADO DE PERNAMBUCO, 5., 2013, Recife. Anais... Recife: UFPE, 2013. p. 1-12.

RIGOTTI, J. A.; POMPÊO, C. A. Assessment of urban stream condition: case study. In: INTERNATIONAL CONFERENCE ON URBAN DRAINAGE, 12., 2011, Porto Alegre. Anais... Porto Alegre: ABRH/IWA, 2011. p. 1-8.
SANTOS, R. F. Planejamento ambiental: teoria e prática. São Paulo: Oficina de Textos, 2004.

SILVA, P. O.; CABRAL, J. J. S. P. Atenuação de Picos de vazão em área problema: estudo comparativo de reservatórios de detenção em lote, em logradouros e em grande área da bacia. RBRH: Revista Brasileira de Recursos Hídricos, v. 19, n. 2, p. 7-18, 2014. http:// dx.doi.org/10.21168/rbrh.v19n2.p7-18.

SIMONOVIC, S. P.; VERMA, R. A new methodology for water resources multicriteria decision making under uncertainty. Physics an Chemistry ob the Earth, v. 33, p. 322-329, 2008.

TUCCI, C. E. M. Gerenciamento da drenagem urbana. RBRH: Revista Brasileira de Recursos Hídricos, v. 7, n. 1, p. 5-27, 2002.

VINCKE, P. Multicriteria decision aid. Bruxelles: Jonh Wiley \& Sons, 1992.

ZUFFO, A.C.; REIS, L.F.R.; SANTOS, R.F.; CHAUDRY, F.H. Aplicação de métodos multicriteriais ao planejamento de recursos hídricos. RBRH: Revista Brasileira de Recursos Hídricos, v. 7, n. 1, p. 81-102, 2002.

\section{Authors contributions}

Danniel Cláudio de Araújo: Work conception, performed bibliographic research, data collection and treatment, data analysis, results discussion and article writing.

Pedro Oliveira da Silva: Data collection and treatment and article writing.

Wilson Fadlo Curi: Work conception, data analysis, results discussion and article writing.

Jaime Joaquim da Silva Pereira Cabral: Work conception, data analysis, results discussion and article writing. 